\title{
Impact of Frequency of Testing on Study Habits and Achievement in Mathematics Among Secondary School Students in Ogun State, Nigeria
}

\author{
Oluwatomi Modupeola Alade \\ University of Lagos \\ Olaotan Oladele Kuku \\ University of Lagos
}

This study examined the impact of frequent of testing on study habits and achievement in mathematics among public secondary school students in Ogun State, Nigeria. Two out of the four research hypotheses postulated were accepted, whereas the remaining two were rejected. The findings showed that there were significant differences in the mean scores of students' achievement in mathematics and study habits as a result of exposing students to varying test frequencies. In addition, the study revealed that gender is not a significant factor when planning to improve study habits and achievement in mathematics. On the basis of these findings, test frequency of every 2 weeks was recommended to improve students' academic achievement in mathematics.

Keywords: frequency of testing, study habits, assessment, achievement in mathematics

\section{Introduction}

The knowledge of mathematics is important in every individual's daily life and across diverse human disciplines. As a result, Anaduaka and Okafor (2013) opined that mathematics is one subject that affects virtually every field of human endeavor. Similarly, in the Nigerian school system, Tella (2007) described mathematics as an important school subject that is associated with academic and career opportunities. Hence, Jaiyeoba and Atanda (2011) reported that in the Nigerian school system, mathematics is one of the compulsory subjects that students study in the senior secondary school, irrespective of their departments or class (that is, science, commercial, or arts class).

The extent to which such classroom activities and learning take place is judged using the students' academic achievement. Good (in Ganai \& Mirashraf, 2013) referred to academic achievement as the knowledge obtained or skills developed in the school subjects usually designated by test scores or marks assigned by the teacher. In spite of the importance accorded to mathematics in the society, students' achievement has been below average at the secondary school level of education in Nigeria. Students' performance in external examinations such as the Senior Secondary Certificate Examination showed that students do not perform up to the expected level.

The West African Examination Council's report between 2010 and 2014 presented in Table 1 shows that an average of $41 \%$ out of more than 1.5 million entrants passed mathematics at credit level and above. The low scores recorded in the examinations may not be a true reflection of the students' abilities. Such low achievements could be linked to the technique of testing/assessment and poor study habits, among others. 


\begin{tabular}{lccc}
$\begin{array}{r}\text { Table 1: Statistics of May/June (Senior Secondary Certificate Examination) } \\
\text { Performance (Nigeria) From 2010 to 2014 }\end{array}$ \\
\hline Year & Total Entry & Total Pass at Credit Level and Above & Percentage Pass \\
\hline 2010 & $1,351,557$ & 534,841 & $40 \%$ \\
2011 & $1,540,250$ & 587,630 & $38 \%$ \\
2012 & $1,672,224$ & 649,156 & $39 \%$ \\
2013 & $1,543,683$ & 889,636 & $58 \%$ \\
2014 & $1,692,435$ & 529,427 & $31 \%$ \\
Average & $1,560,030$ & 638,138 & $41 \%$ \\
\hline
\end{tabular}

Source: West African Examination Council (2010-2014), Research Division annual reports.

Crede and Kuncel (2008) defined study habits as study routines, including but not restricted to frequency of studying sessions, review of material, self-testing, rehearsal of learned material, and studying in a conducive environment. Aquino (2011) carried out a research on students' study habits and attitudes where he observed a strong relationship between study habits and academic performance. In the Nigerian secondary school system and during instruction, teachers are expected to evaluate students' understanding on topics taught. They also give take-home exercises and projects to aid further understanding of the lesson. Besides, the regularity of testing should help to improve the students' study behavior/pattern in mathematics. Academic activities such as class exercise, take-home exercises, and testing are expected to enable students to develop study habits or behavior, which will affect the amount of information students add to their memory. Adeyemo (2005) stated that study habits go beyond reading for pleasure; he perceived them as planned, deliberate, and consistent efforts made by students toward the understanding of their academic subjects that help in their academic achievement.

In Nigeria, the assessment of learners' achievement used to be based purely on a one-time examination, usually administered at the end of the term or school year. Its numerous defects, such as poorly accounting for students' cognitive, affective, and psychomotor abilities throughout the entire academic period, led to the introduction of continuous assessment (O'Kwu \& Orum, 2012). Section 1 of the National Policy on Education (Federal Republic of Nigeria, 2013), which deals with the philosophy and goals of education in Nigeria, states that "educational assessment and evaluation shall be liberalised by their being based in whole or in part on continuous assessment of the progress of the individual" (para. 9[g]). However, after the teacher might have taught all the scheduled scheme of work, the frequency at which the students are exposed to testing might assist in making students familiar with the way tests are constructed and administered to capture students' knowledge in the subject. In addition, such testing method and rates could influence students' study habits.

In the view of Deck (2008), frequent testing is perceived as testing students every week, excluding the final examination. Shirvani (2009) considered frequent testing as ranging from administering tests more than once in a term or semester, to giving tests once a week, to giving them daily. Thus, frequency of testing refers to the rate(s) of test administration, usually during the term or semester other than the end-of-term/year examination. Shirvani (2007), Zgraggen (2009), and Marcell (2008) reported that when testing was frequent, students would be engaged and that getting the students to respond to questions and discuss read materials would positively affect their academic achievement. Another research study showed that when frequency of testing increased, there was an increase in students' involvement, responses to questions, and discussion of reading materials (Marcell, 2008). Haigh (2007) found that regular testing was popular with students because it reinforced students' engagement with the course and provided immediate positive feedback. 
Testing is a part of assessment. Assessment is defined as any procedure or activity that is designed to collect information about the knowledge, attitude, or skills of the learner or group of learners (Greaney, 2001; Mwebaza, 2010). However, when an assessment is carried out as an ongoing process, it is referred to as continuous assessment (Mwebaza, 2010). Continuous assessment involves every decision made by the teacher in class to improve students' achievement in the cognitive, affective, and psychomotor domains of learning (Federal Ministry of Education, Science, and Technology, 1985; Mwebaza, 2010). Continuous assessment may take different forms such as formal questions given to students during class (tests), take-home assignments/exercises, projects, practicals, and recapitulation exercises. In the school system, and with particular emphasis on testing, it could be observed that giving students continuous short tests during classroom learning should not put students under great pressure, as the final examination does at the end of the term and during school certificate examination.

Frequent testing during teaching and before school examinations offer students interim feedback on their performances, allowing them to know if their study efforts are appropriate and to become aware of their areas of strengths and weaknesses. On the other hand, when tests given to students are too frequent, they might not have enough time to deepen their knowledge and to understand the relationships among the range of concepts covered in a given subject. This has led to the question of how tests are used during students' learning. Although the Nigerian National Policy on Education supports the use of continuous assessment during teaching and learning, the rates at which students should be tested to achieve desirable and satisfactory students' achievement is yet to be ascertained. In the same vein, such testing methods should induce and inculcate an ideal study habits that will improve students' achievement.

\section{Statement of the Problem}

The performance of students in mathematics in the Senior Secondary Certificate Examination has been poor, despite the fact that the subject has obvious application to students' immediate environment and across various human endeavors. Students' academic achievements determine their readiness and suitability for higher educational studies and employment. In view of these, learners' study habits are expected to reflect in their achievement. Learners who have poor routine of reading or bad study habits might find it difficult recalling learned concepts, particularly when assessment is not carried out repeatedly.

Assessment, particularly an achievement test, is used in various ways to achieve specific objectives. While in the classroom, the role of the teacher is to conduct learning to the understanding of the learners. Testing is one tool that could be efficacious in assisting the students form an effective study habits that would improve their achievement in mathematics. Hence, this study seeks to determine an effective frequency at which students should be tested during instruction that will improve study habits and achievement in mathematics. 


\section{Research Hypotheses}

The following hypotheses guided the study.

\section{Hypothesis 1}

Ho: Achievement scores in mathematics will not significantly differ among students exposed to varying test frequencies.

$\mathrm{H}_{1}$ : Achievement scores in mathematics significantly differ among students exposed to varying test frequencies.

\section{Hypothesis 2}

Ho: Study habits will not significantly differ among students exposed to the varying test frequencies.

$\mathrm{H}_{1}$ : Study habits significantly differ among students exposed to the varying test frequencies.

\section{Hypothesis 3}

Ho: Achievement scores in mathematics will not significantly differ among students exposed to the varying frequencies by gender.

$\mathrm{H}_{1}$ : Achievement scores in mathematics will significantly differ among students exposed to the varying frequencies by gender.

\section{Hypothesis 4}

$\mathrm{H}_{\mathrm{o}}$ : There is no significant difference in the study habits of students exposed to the varying test frequencies by gender.

$\mathrm{H}_{1}$ : There is significant difference in the study habits of students exposed to the varying test frequencies by gender.

\section{Methodology}

\section{Research Design}

A quasiexperimental pretest/posttest control group research design was used for this study.

\section{Population of the Study}

The population of the study consisted of all Senior Secondary 2 students in public senior secondary schools in Ogun State.

\section{Sample and Sampling Techniques}

A multistage sampling process was used to select the sample for this study. The first stage involved using simple random sampling method to select one of the four geopolitical divisions (or strata) in Ogun State (i.e., Remo, Ijebu, Yewa, and Egba). The next stage involved using simple random 
sampling to select five local education zones. Afterward, one coeducational secondary school was selected through simple random sampling from the five local education zones earlier selected.

Out of the five schools selected for the study, four were subjected to varying rates of testing and the remaining group was the control group. All the participants selected for the final studies scored below 40\% in their Mathematics Achievement Test (MAT) and below 55\% in Study Habit Inventory (SHI). The participants who qualified for inclusion in the experimental program were randomly assigned into the experimental groups as shown in Table 2. Table 2 also describes the order in which the topics were taught weekly and the rate at which the experimental groups were tested.

Table 2: Distribution of Students in the Preassessment Selection for Baseline Data and Testing Groups

\begin{tabular}{|c|c|c|c|c|c|c|c|}
\hline \multirow{2}{*}{$\begin{array}{l}\text { Schools } \\
\text { (Testing Groups) }\end{array}$} & \multicolumn{3}{|c|}{ Preassessment Participants } & \multirow{2}{*}{$\begin{array}{c}\text { Frequency of } \\
\text { Testing }\end{array}$} & \multicolumn{3}{|c|}{ Experimental Participants } \\
\hline & Male & Female & Total & & Male & Female & Total \\
\hline School A & 27 & 31 & 58 & Weekly & 16 & 17 & 33 \\
\hline School B & 23 & 26 & 49 & 2 Weeks & 14 & 17 & 31 \\
\hline School C & 26 & 22 & 48 & 3 Weeks & 16 & 15 & 31 \\
\hline School D & 22 & 21 & 43 & 4 Weeks & 16 & 16 & 32 \\
\hline School E & 23 & 29 & 52 & Control (no test) & 14 & 16 & 30 \\
\hline Total & 121 & 129 & 250 & Total & 76 & 81 & 157 \\
\hline
\end{tabular}

Figures in Table 2 show that a total sample of 250 students was pretested on the MAT and SHI instruments across the selected schools. A total of 187 students qualified and started the periodic testing conditions, whereas 157 students ( 76 male and 81 female) completed the periodic testing program.

\section{Instrument}

Two research instruments were used to collect data for the study: the MAT and SHI.

\section{Mathematics Achievement Test (MAT)}

The MAT was constructed and refined by the researchers. The instrument comprised three sections (Sections A, B, and C). Section A was aimed at getting the background data of students. Section B had 50 multiple-choice items, which had obtainable score of 50, and Section $\mathrm{C}$ was the theory part, consisting of three questions that attracted 50 marks. In order to align the objectives, content covered, and assessments, a test blueprint (Alade \& Igbinosa, 2014) was developed based on the first term's scheme of work for mathematics by the Ogun State Federal Ministry of Education, Science, and Technology as shown in Table 3. These items were also validated by experts in the Department of Mathematics Education and Measurement and Evaluation. Item analysis was carried out during the pilot study, and the indices of difficulty ranged from 0.2 to 0.8 . All the discrimination indices were positive values (Ilogu, 2005). Test-retest reliability was used to measure the consistency of the instruments, which generated a reliability coefficient of 0.81 . 
Table 3: Testing Rate and Test Blueprint for the 50-Item Multiple-Choice Objective Mathematics Test

\begin{tabular}{|c|c|c|c|c|c|c|c|c|}
\hline Item & Topics & $\begin{array}{c}\text { School } \\
\text { Testing } \\
\text { Rate }\end{array}$ & $\begin{array}{l}\text { Week(s) } \\
\text { Schedule }\end{array}$ & $\begin{array}{c}\text { Weight } \\
(\%)\end{array}$ & $\begin{array}{c}\text { Knowledge } \\
22 \%\end{array}$ & $\begin{array}{c}\text { Comprehension } \\
34 \% \\
\end{array}$ & $\begin{array}{c}\text { Application } \\
44 \%\end{array}$ & Total \\
\hline 1 & Logarithm & $\mathrm{A}$ & 2 & 24 & 3 & 4 & 5 & 12 \\
\hline 2 & Logarithm & $\mathrm{A}, \mathrm{B}$ & & & & & & \\
\hline 3 & Circle theorem & $\mathrm{A}, \mathrm{C}$ & 3 & 22 & 2 & 4 & 5 & 11 \\
\hline 4 & Circle theorem & $\mathrm{A}, \mathrm{B}, \mathrm{D}$ & & & & & & \\
\hline 5 & Circle theorem & $\mathrm{A}$ & & & & & & \\
\hline 6 & $\begin{array}{l}\text { Approximation } \\
\text { and error }\end{array}$ & $\mathrm{A}, \mathrm{B}, \mathrm{C}$ & 1 & 16 & 2 & 3 & 3 & 8 \\
\hline 7 & $\begin{array}{l}\text { Quadratic } \\
\text { equation }\end{array}$ & $\mathrm{A}$ & 2 & 18 & 2 & 3 & 4 & 9 \\
\hline 8 & $\begin{array}{l}\text { Quadratic } \\
\text { equation }\end{array}$ & $\mathrm{A}, \mathrm{B}$ & & & & & & \\
\hline 9 & $\begin{array}{c}\text { Measure of } \\
\text { central tendency }\end{array}$ & A, C, D & 1 & 20 & 2 & 3 & 5 & 10 \\
\hline Total & & & 9 & 100 & 11 & 17 & 22 & 50 \\
\hline
\end{tabular}

\section{Study Habit Inventory (SHI)}

The researchers adapted the SHI by Bakare (1977) to find out students' learning habits using five subdivisions (see Appendix). The subdivisions are homework and assignment, time allocation, reading and note taking, study period procedures/test preparation, and examinations/test taking. The instrument has a reliability coefficient of 0.73 , and the adapted instrument has a reliability coefficient of 0.75 using the Cronbach alpha reliability tool. The researchers obtained a concurrent validity coefficient of 0.76 when validated with the original instrument. The SHI consisted of Sections A and B. Section A deals with the personal data of respondents, whereas Section B has five parts, which contained 37 statements that deal with the main sources of students' study habits problems with a focus on mathematics. The response to each of the items contained the following options: 1 (almost never), 2 (less than half of the time), 3 (more than half of the time), and 4 (almost always).

\section{Administration of Instruments/Data Collection}

The administration of the instruments lasted for 11 weeks. Eight research assistants were recruited for the study. The research assistants have a minimum qualification of bachelor degrees in education from the University of Lagos and Olabisi Onabanjo University, Ogun State. In addition, they have a minimum of 5 years of postdegree experiences. The instruments were administered to the participants in groups by the researchers with the help of the research assistants. The details of the experiment procedure follow. 


\section{Procedure}

This was carried out in three phases.

Phase 1: Pretesting periods: On resumption for the first-term 2014/2015 academic session, a baseline assessment (or pretest) was conducted for all the 250 students selected across the five secondary schools using the MAT and SHI. The participants selected for the study had below $40 \%$ score on the MAT I and 55\% score on the SHI. A total of 185 students qualified and started the experiment.

Phase 2: Testing periods: There were five experimental groups. The students in schools/groups were taught by the researchers with the same lesson plans and notes. After the instruction, the students in the groups were given multiple-choice questions containing 15 items. The students were given 25 min to attempt the 15 items multiple-choice questions. Marking of the multiple-choice questions and corrections were done in class. However, the rates at which the groups were tested varied. Four groups were exposed to varying frequencies of testing during teaching/instruction in the course of the study, whereas the fifth group (that is, the control group) was not given the test. Group 1 (School A) was tested every week. Group 2 (School B) was tested every 2 weeks. Groups 3 (School C) and 4 (School D) were tested every 3 and 4 weeks, respectively. The sequence of instructions and testing rates per school is provided in Table 2 . The classes in a school were scheduled for 4 periods (with a period lasting for $40 \mathrm{~min}$ on the scheduled timetable) in a week for 9 weeks with a total of $160 \mathrm{~min}$ of lesson session per week to teach students based on topics in the Ogun State Federal Ministry of Education, Science, and Technology's Scheme of Work for first term in senior secondary schools. The classes took place in the mornings, before their long break that was scheduled for noon on their timetables. However, apart from teaching the term's topics, the control group was not given any test during the study period.

Phase 3: Posttesting periods. In the 11th week, after the experiment was completed, the researchers readministered the MAT and SHI to all the participants in the experimental and control groups to gather posttest data.

\section{Method of data analysis}

Means, standard deviations, and analyses of covariance (ANCOVAs) were used to analyze the data. All hypotheses were tested at a .05 level of significance.

\section{Testing of hypotheses/results obtained}

Hypothesis 1: Achievement scores in mathematics will not significantly differ among students exposed to varying test frequencies. A cursory look at Table 4 shows that School A had a pretest score of 20.55, and School B had a pretest score of 20.03. School C, School D, and School E had 20.06, 20.87 , and 20.77 , respectively. 
Table 4: Descriptive Data on Pretest and Posttest Scores on the Mathematics Achievement Test Among Students Exposed to the Experimental Conditions

\begin{tabular}{lcccccccc}
\hline \multirow{2}{*}{$\begin{array}{l}\text { School } \\
\text { Category }\end{array}$} & Testing Period & $N$ & $M$ & $S D$ & $N$ & $M$ & $S D$ & Mean \\
\cline { 2 - 7 } Difference \\
\hline School A & 1-Week testing & 33 & 20.55 & 5.61 & 33 & 60.6 & 9.24 & 40.05 \\
School B & 2-Week testing & 31 & 20.03 & 2.63 & 31 & 61.1 & 6.7 & 41.07 \\
School C & 3-Week testing & 31 & 20.06 & 4.49 & 31 & 42.65 & 8.01 & 22.59 \\
School D & 4-Week testing & 32 & 20.87 & 6.17 & 32 & 40.13 & 6.5 & 19.26 \\
School E & Control group & 30 & 20.77 & 4.21 & 30 & 39.17 & 11.46 & 18.4 \\
Grand total/average & 157 & 20.46 & 4.76 & 157 & 48.89 & 13.1 & 28.43 \\
\hline
\end{tabular}

Table 4 also shows that at posttest, Schools A, B, C, D, and E had mean scores of 60.6, 61.1, 42.65, 40.13 , and 39.17, respectively. The table further shows that School B (2-week testing) had the highest mean difference of 41.07 , above the average mean difference of 28.43 .

To determine whether there was significant difference in MATs as a result of experimental conditions, an ANCOVA was done (see Table 5).

Table 5: Analysis of Covariance on Mathematics Achievement Test Among the Experimental Groups

\begin{tabular}{lcccc}
\hline Source & Sum of Squares & $d f$ & Mean Square & $F$ \\
\hline Corrected model & $16,237.61$ & 5 & $3,247.52$ & $46.55^{*}$ \\
Intercept & $12,987.61$ & 1 & $12,987.61$ & $186.17^{*}$ \\
Covariate & 585.03 & 1 & 585.03 & $8.39^{*}$ \\
Experimental groups & $15,846.44$ & 4 & $3,961.61$ & $56.79^{*}$ \\
Error & $10,534.32$ & 151 & 69.76 & \\
Corrected total & $26,771.94$ & 156 & & \\
\hline
\end{tabular}

* Significant at $p<.05 ; F_{\text {critical }}$ at $0.05(4,151)=2.37$.

The data in Table 5 shows that a calculated $F$ value of 56.79 resulted as the difference in achievement in MAT among the experimental groups. Because the $F$ value of 56.79 is greater than

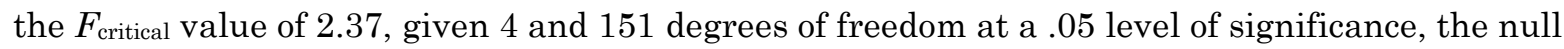
hypothesis was rejected and alternative hypothesis accepted. This indicates that achievement scores in mathematics significantly differ among students exposed to varying test frequencies. To determine the degree of difference in the experimental conditions in the MAT, least squares difference post hoc multiple comparison was carried out (see Table 6).

Table 6: Multiple Comparison of Mathematics Achievement Test and Experimental Groups

\begin{tabular}{lccc}
\hline & $\begin{array}{c}\text { Experimental Groups } \\
\text { Experimental Groups (I) }\end{array}$ & $\begin{array}{c}\text { Mean Difference } \\
(\mathrm{I}-\mathrm{J})\end{array}$ & $p$ \\
\hline School A & School C & $17.765^{*}$ & .000 \\
& School D & $20.616^{*}$ & .000 \\
\multirow{3}{*}{ School B } & School E & $21.530^{*}$ & .000 \\
& School C & $18.465^{*}$ & .000 \\
& School D & $21.316^{*}$ & .000 \\
& School E & $22.230^{*}$ & .000 \\
\hline
\end{tabular}

* Significant at $p<.05$. 
Table 6 shows that participants in School A had significant mean difference when compared to Schools C (mean difference $=17.765 ; p=.000)$, D (mean difference $=20.616 ; p=.000)$, and $\mathrm{E}$ (mean difference $=21.530 ; p=.000)$. Also, School B had significant mean difference when compared to Schools C (mean difference $=18.465 ; p=.000)$, D (mean difference $=21.316 ; p=.000)$, and $\mathrm{E}($ mean difference $=22.230 ; p=.000$ ). This indicates that participants tested weekly and every 2 weeks (i.e., Schools A and B) had significantly better achievement in mathematics when compared with other experimental groups. Besides, the result shows no significant difference in the achievement between schools exposed to weekly (School A) and 2-week testing (School B).

Hypothesis 2: Study habits will not significantly differ among students exposed to the varying testing frequencies. The descriptive data presented in Table 7 indicates that the five experimental groups obtained pretest mean scores ranging from 79.94 for School A, 79.35 for School B, 79.77 for School C, 78.84 for School D, to 80.93 for School E. The table also shows that at posttest, Schools A, B, C, D, and $\mathrm{E}$ had mean differences of 101.76, 101.16, 102.65, 107.47, and 100.23, respectively. School D (4week testing) had the highest mean difference of 28.63 , above the average mean difference of 22.88 .

Table 7: Descriptive Data on Pretest and Posttest Scores of Study Habits Among Students Exposed to the Experimental Conditions

\begin{tabular}{|c|c|c|c|c|c|c|c|c|}
\hline \multirow[b]{2}{*}{ School Category } & \multirow[b]{2}{*}{ Testing Period } & \multicolumn{3}{|c|}{ Pretest } & \multicolumn{3}{|c|}{ Posttest } & \multirow{2}{*}{$\begin{array}{c}\text { Mean } \\
\text { Difference }\end{array}$} \\
\hline & & $N$ & $M$ & $S D$ & $N$ & $M$ & $S D$ & \\
\hline School A & 1-Week testing & 33 & 79.94 & 11.43 & 33 & 101.76 & 8.72 & 21.82 \\
\hline School B & 2-Week testing & 31 & 79.35 & 9.55 & 31 & 101.16 & 8.17 & 22.81 \\
\hline School C & 3-Week testing & 31 & 79.77 & 15.44 & 31 & 102.65 & 12.72 & 22.87 \\
\hline School D & 4-Week testing & 32 & 78.84 & 11.04 & 32 & 107.47 & 7.32 & 28.63 \\
\hline School E & Control group & 30 & 80.93 & 11.09 & 30 & 100.23 & 8.53 & 19.3 \\
\hline Grand total/average & & 157 & 79.77 & 11.71 & 157 & 102.62 & 9.09 & 22.88 \\
\hline
\end{tabular}

To determine if these differences were statistically significant, the data was subjected to ANCOVA, and the results in Table 8 were obtained.

Table 8: Analysis of Covariance on Study Habits Among the Experimental Groups

\begin{tabular}{lcccc}
\hline Source & Sum of Squares & $d f$ & Mean Square & $F$ \\
\hline Corrected model & $2,171.99$ & 5 & 434.40 & $5.51^{*}$ \\
Intercept & $23,303.19$ & 1 & $23,303.19$ & $295.55^{*}$ \\
Covariate & $1,158.97$ & 1 & $1,158.97$ & $14.70^{*}$ \\
Experimental groups & $1,113.64$ & 4 & 278.41 & $3.53^{*}$ \\
Error & $11,905.72$ & 151 & 78.85 & \\
Corrected total & $14,077.71$ & 156 & & \\
\hline
\end{tabular}

* Significant at $p<.05 ; F_{\text {critical }}$ at $0.05(4,151)=2.37$.

The results in Table 8 reveal that a calculated $F$ value of 3.53 resulted as the difference in study habits among the experimental conditions. Thus, the calculated $F$ value is statistically significant

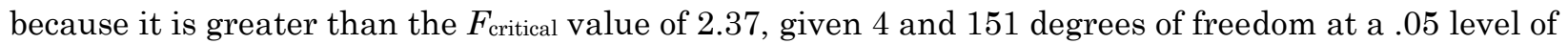
significance. Thus, the null hypothesis was rejected and alternative hypothesis accepted. This implies that study habits significantly differed among students exposed to the varying test frequencies. In order to determine the degree of difference in the experimental conditions in Study Habits, Fisher's least squares difference post hoc multiple comparison was carried out and the outcome is presented in Table 9. 
Table 9: Multiple Comparison of Study Habits Among the Experimental Groups

\begin{tabular}{lccc}
\hline $\begin{array}{l}\text { Experimental Groups } \\
\text { (I) }\end{array}$ & $\begin{array}{c}\text { Experimental Groups } \\
(\mathrm{J})\end{array}$ & $\begin{array}{c}\text { Mean Difference } \\
(\mathrm{I}-\mathrm{J})\end{array}$ & $p$ \\
\hline School D & School A & $5.966^{*}$ & .008 \\
& School B & $6.426^{*}$ & .005 \\
& School C & $5.040^{*}$ & .026 \\
& School E & $7.722^{*}$ & .001 \\
\hline \hline
\end{tabular}

* Significant at $p<.05$.

Table 9 shows that participants in School D had significant mean difference when paired with Schools A (mean difference $=5.966, p=.008)$, B (mean difference $=6.426, p=.005)$, C (mean difference $=5.04, p=.026$ ), and $\mathrm{E}$ (mean difference $=7.722, p=.001$ ). As a result, it was evident that participants in School D (4-week testing) spent the most time studying when compared with other participants in their respective groups.

Hypothesis 3: Achievement scores in mathematics will not significantly differ among students exposed to the varying frequencies by gender. Evidence from Table 10 shows that the mean MAT scores for male participants (at pretest) were 21.56 for School A, 20.29 for School B, 21.38 for School C, 22.38 for School D, and 21.00 for School E. Likewise, pretest mean values of MAT scores for the female participants were 19.59 for School A, 19.82 for School B, 18.67 for School C, 19.38 for School $\mathrm{D}$, and 20.56 for School E. The table further shows that at posttest, the male participants in School A had 62.69, School B had 62.29, School C had 46.56, School D had 41.00, and School E had 39.57. The posttest mean scores for female participants show that School A, B, C, D, and E had 58.65, 60.12, $38.47,39.25$, and 38.81 , respectively.

Table 10: Descriptive Data on Effect of Gender and Experimental Conditions on Mathematics Achievement Test Among Participants

\begin{tabular}{lccccccc}
\hline & & \multicolumn{2}{c}{ Pretest } & \multicolumn{2}{c}{ Posttest } & Mean \\
\cline { 5 - 6 } School & Gender & $N$ & $M$ & $S D$ & $M$ & $S D$ & Difference \\
\hline School A (weekly test) & Male & 16 & 21.56 & 5.19 & 62.69 & 10.17 & 41.13 \\
& Female & 17 & 19.59 & 5.97 & 58.65 & 8.08 & 39.06 \\
& Total & 33 & 20.55 & 5.61 & 60.61 & 9.24 & 40.06 \\
School B (2-week test) & Male & 14 & 20.29 & 3.00 & 62.29 & 5.88 & 42.00 \\
& Female & 17 & 19.82 & 2.35 & 60.12 & 7.33 & 40.29 \\
& Total & 31 & 20.03 & 2.63 & 61.10 & 6.70 & 41.06 \\
School C (3-week test) & Male & 16 & 21.38 & 5.24 & 46.56 & 6.23 & 25.19 \\
& Female & 15 & 18.67 & 3.11 & 38.47 & 7.74 & 19.80 \\
& Total & 31 & 20.06 & 4.49 & 42.65 & 8.01 & 22.58 \\
School D (4-week test) & Male & 16 & 22.38 & 7.07 & 41.00 & 8.63 & 18.63 \\
& Female & 16 & 19.38 & 4.90 & 39.25 & 3.36 & 19.88 \\
School E (control & Total & 32 & 20.88 & 6.17 & 40.13 & 6.50 & 19.25 \\
group) & Male & 14 & 21.00 & 4.47 & 39.57 & 13.70 & 18.57 \\
& Female & 16 & 20.56 & 4.10 & 38.81 & 9.52 & 18.25 \\
Grand total/average & Total & 30 & 20.77 & 4.21 & 39.17 & 11.46 & 18.40 \\
& Male & 76 & 21.32 & 4.99 & 50.42 & 8.92 & 29.10 \\
& Female & 81 & 19.6 & 4.09 & 47.06 & 7.2 & 27.46 \\
\hline \hline
\end{tabular}


Thus, it is observed that male (42.0) and female (40.29) participants in School B with periodic testing every 2 weeks had the highest achievement above the average mean difference of 29.1 and 27.46, respectively. To determine whether significant difference existed on mathematics achievement due to gender and experimental conditions, ANCOVA statistics was used (see Table 11).

Table 11: Analysis of Covariance on the Effect of Gender and Experimental Conditions on Mathematics Achievement Test

\begin{tabular}{lcccc}
\hline Source & Sum of Squares & $d f$ & Mean Square & $F$ \\
\hline Corrected model & $16,751.53$ & 10 & $1,675.15$ & $24.41^{*}$ \\
Intercept & $13,252.51$ & 1 & $13,252.51$ & $193.09^{*}$ \\
Covariate & 392.07 & 1 & 392.07 & $5.71^{*}$ \\
Experimental groups & $15,897.83$ & 4 & $3,974.46$ & $57.91^{*}$ \\
Gender & 291.01 & 1 & 291.01 & $4.24^{*}$ \\
Experimental groups/gender & 225.01 & 4 & 56.25 & 0.82 \\
Error & $10,020.41$ & 146 & 68.63 & \\
Corrected total & $26,771.94$ & 156 & & \\
\hline
\end{tabular}

* Significant at $p<.05 ; F_{\text {critical }}$ at $0.05(4,151)=2.37$.

The results in Table 11 show a calculated $F$ value of 0.82 as the interaction effect between gender and the experimental conditions. This is not significant because it is less than the $F_{\text {critical value of }}$ 2.37, given 4 and 146 degrees of freedom at a .05 level of significance. Thus, the null hypothesis was accepted, indicating that achievement scores in mathematics will not significantly differ among students exposed to the varying frequencies by gender.

Hypothesis 4: There is no significant difference in the study habits of students exposed to the varying test frequencies by gender. Evidence from Table 12 shows that the pretest study habits scores for male students were 80.50 for School A, 84.07 for School B, 80.38 for School C, and 78.56 for School D, while School E scored 79.21. Likewise, the pretest mean score value of study habits for female students were 79.41 for School A, 75.47 for School B, 79.13 for School C, 79.13 for School D, and 82.44 for School E. Also, at posttest, male participants in Schools A, B, C, D, and E had mean scores of 101.19, 104.86, 104.88, 107.13, and 99.57, respectively. Their female counterparts had mean scores of 103.24, 98.12, 100.27, 107.81, and 100.81, respectively. 
Table 12: Descriptive Data on Effect of Gender and Experimental Conditions on Study Habits Among Participants With Reference to Gender

\begin{tabular}{|c|c|c|c|c|c|c|c|}
\hline \multirow[b]{2}{*}{ School } & \multirow[b]{2}{*}{ Gender } & \multirow[b]{2}{*}{$N$} & \multicolumn{2}{|c|}{ Pretest } & \multicolumn{2}{|c|}{ Posttest } & \multirow{2}{*}{$\begin{array}{c}\text { Mean } \\
\text { Difference }\end{array}$} \\
\hline & & & $M$ & $S D$ & $M$ & $S D$ & \\
\hline \multirow[t]{3}{*}{ School A (weekly test) } & Male & 16 & 80.50 & 12.27 & 101.19 & 9.22 & 19.69 \\
\hline & Female & 17 & 79.41 & 10.93 & 103.24 & 8.22 & 23.82 \\
\hline & Total & 33 & 79.94 & 11.43 & 101.76 & 8.72 & 21.82 \\
\hline \multirow[t]{3}{*}{ School B (2-week test) } & Male & 14 & 84.07 & 9.83 & 104.86 & 8.47 & 20.79 \\
\hline & Female & 17 & 75.47 & 7.55 & 98.12 & 6.71 & 22.65 \\
\hline & Total & 31 & 79.35 & 9.55 & 101.16 & 8.17 & 21.81 \\
\hline \multirow[t]{3}{*}{ School C (3-week test) } & Male & 16 & 80.38 & 15.51 & 104.88 & 11.74 & 24.50 \\
\hline & Female & 15 & 79.13 & 15.88 & 100.27 & 13.70 & 21.13 \\
\hline & Total & 31 & 79.77 & 15.44 & 102.65 & 12.72 & 22.87 \\
\hline \multirow[t]{3}{*}{ School D (4-week test) } & Male & 16 & 78.56 & 9.70 & 107.13 & 6.56 & 28.56 \\
\hline & Female & 16 & 79.13 & 12.55 & 107.81 & 8.22 & 24.69 \\
\hline & Total & 32 & 78.84 & 11.4 & 107.47 & 7.32 & 28.63 \\
\hline \multirow[t]{4}{*}{ School E (control group) } & Male & 14 & 79.21 & 8.95 & 99.57 & 9.66 & 20.36 \\
\hline & Female & 16 & 82.44 & 12.78 & 100.81 & 7.69 & 18.38 \\
\hline & Total & 30 & 80.93 & 11.09 & 100.23 & 8.53 & 19.30 \\
\hline & Male & 76 & 80.54 & 11.25 & 103.32 & 9.13 & 22.78 \\
\hline \multirow[t]{2}{*}{ Grand total/average } & Female & 81 & 79.12 & 11.94 & 102.05 & 8.91 & 22.93 \\
\hline & Total & 157 & 79.77 & 11.71 & 102.65 & 9.09 & 22.88 \\
\hline
\end{tabular}

Table 12 further indicates that the male (28.56) and female (24.69) students in School D (with 4week testing) had the highest study habits, with mean differences above the averages of 22.78 and 22.93, respectively. To determine whether significant differences existed on study habits due to gender and experimental conditions, ANCOVA statistics were used. The results are presented in Table 13.

Table 13: Analysis of Covariance on the Effect of Gender and Experimental Conditions on Study Habit

\begin{tabular}{lcccc}
\hline Source & Sum of Squares & $d f$ & Mean Square & $F$ \\
\hline Corrected model & $2,588.47$ & 10 & 258.85 & $3.29^{*}$ \\
Intercept & $23,269.55$ & 1 & $23,269.55$ & $295.70^{*}$ \\
Covariate & 970.48 & 1 & 970.48 & $12.33^{*}$ \\
Experimental groups & $1,091.53$ & 4 & 272.88 & $3.47^{*}$ \\
Gender & 36.27 & 1 & 36.27 & 0.46 \\
Experimental groups/gender & 385.96 & 4 & 96.49 & 1.23 \\
Error & $11,489.24$ & 146 & 78.69 & \\
Corrected total & $14,077.71$ & 156 & & \\
\hline
\end{tabular}

* Significant at $p<.05 ; F_{\text {critical }}$ at $0.05(4,151)=2.37$.

Evidence from Table 13 shows that a calculated $F$ value of 1.226 was obtained as a result of the interaction effect between the experimental groups and gender. This value is not significant because

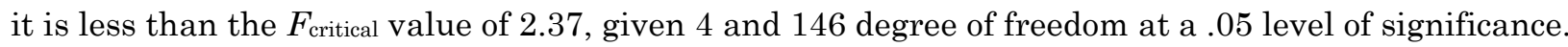
Hence, Null Hypothesis 4 was accepted, implying that there was no significant difference in the study habits of students exposed to the varying test frequencies by gender. 


\section{Discussion of Findings}

Null Hypothesis 1 states that achievement scores in mathematics will not significantly differ among students exposed to varying test frequencies. The study led to the rejection of the null hypothesis and accepting the alternative hypothesis. This research showed that a significant difference exists in the students' MAT mean scores when exposed to the varying test frequencies. The findings showed schools that tested every 2 weeks, followed by the school tested weekly, yielded more impact toward reaching improved mean academic achievement than the other experimental groups (i.e., schools that tested every 3 and 4 weeks). The mean achievement of participants in the control group was the least. The finding is in line with the study of Deck (2008), who found a significant difference in achievement in the students tested weekly versus the monthly group. In other similar studies, it was observed that students in the treatment group undertaking the intermediate examination performed better and got better grades than those in the control group (Shirvani, 2009; De Paola \& Scoppa, 2010). In addition, the findings align with Zgraggen's (2009) observation that students who were tested on a biweekly basis scored better on the final exam than the weekly tested group.

Null Hypothesis 2 states that study habits will not significantly differ among students exposed to the varying test frequencies. The findings revealed that there was a significant difference in the scores on study habits among students exposed to the experimental conditions. As a result, the alternative hypothesis was accepted. This finding aligns with the findings of De Paola and Scoppa (2010), who observed that students tested frequently had probability of passing examinations, whereas Sadia (2005) and Abid (2006) noted that effective study habits help students reach satisfactory academic achievement among secondary school students. However, the finding contradicts the study of Fakeye and Amao (2013), who observed no significant relationship between study habits and students' achievement in literature in English. Also, it differs from the findings of Zgraggen (2009) that students tested less frequently adjusted to school and their testing method better than the students tested more frequently.

Null Hypothesis 3 states that achievement scores in mathematics will not significantly differ among students exposed to the varying frequencies by gender. The findings led to the acceptance of the null hypothesis. Thus, it was inferred that there were no significant differences in the MAT scores among students exposed to the varying test frequencies by gender. The findings align with those of Parveen, Noor-Ul-Amin, and Nazir (2013); Devine, Fawcett, Szucs, and Dowker (2012); Ayodele (2011); Zhu (2007); Nuthanap (2007); and Joshi (2000), in their separate studies to determine whether gender difference in mathematics performance existed among secondary school students, who all observed that there exists no difference between the performance of male and female students. However, the findings are in contrast with those of Tella (2007), who observed a significant difference in academic achievement with respect to gender.

Null Hypothesis 4 states that there is no significant difference in the study habits of students exposed to the varying test frequencies by gender. The analysis showed that the null hypothesis was accepted. The results showed that there exists no significant difference in the study habits scores among students exposed to the experimental conditions by gender, contradicting Sud and Sujata's (2006) observation. The researchers noted that boys had significantly better study habits than girls. Also, Khurshid, Tanveer, and Qasmi (2012), while studying the relationship between study habits and academic achievement among hostel-living and day-scholar university students, noted that female university students possess more effective study habits and higher academic achievement than male university students. 


\section{Assumptions and Limitations}

The study did not focus on the roles of the parents or home. Rather, it was based on how school activities (through teaching and testing) can improve students' achievement and study habit. The experimental groups were taught for 9 weeks with the same lesson plan and lesson notes. A 15-item multiple-choice test was administered weekly during the 9 weeks, based on the treatment conditions in the experimental groups. The items were marked and corrections were provided by the researchers on the test items after administration.

The approval given by the Ogun State Federal Ministry of Education, Science, and Technology, Department of Secondary Education (Oke-Mosan in Abeokuta) under the recommendation that the study should be carried out within the schools' scheduled academic timetable, class period, and time. In addition, only five schools were selected to fill the five experimental groups designed for the study.

\section{Conclusion and Recommendations}

The findings of this study have shown that schools tested every 2 weeks and weekly yielded more impact toward improved academic achievement than other experimental groups (i.e., schools tested every 3 and 4 weeks), whereas the control group (i.e., the school with no testing) had the least academic achievement. Furthermore, the findings showed no significant interaction effect between gender and experimental conditions among the students in the experimental groups. Also, frequent testing yielded a significant impact on students' study habits across the experimental groups, but School A (weekly testing) had the most efficient study habits. It was observed that gender had no significant influence on the students' study habits in the experimental conditions. Consequently, the following recommendations were made to the Nigerian education system in order to improve achievement and study habits: (a) Frequent testing at 2 weeks or weekly interval should be adopted in teaching and learning in schools, with the aim of improving students' achievement in mathematics; (b) frequent testing (particularly at a weekly interval) should be introduced in schools for effective management of students' workload and study habits in mathematics; and (c) gender should not be given priority when planning to improve students' achievement and study habits in mathematics using frequent testing. 


\section{References}

Abid, H. S. (2006). Effect of guidance services on study attitudes, study habits and academic achievement of secondary school students. Bulletin of Education \& Research, 28, 35-45.

Adeyemo, B. J. (2005). Effects of study habits modification and test taking strategies on academic performance of secondary school students in Nigeria (Doctoral thesis). University of AdoEkiti, Ekiti State, Nigeria.

Alade, O. M., \& Igbinosa, V. O. (2014). Table of specification and its relevance in educational development assessment. European Journal of Educational \& Development Psychology, 2, 117.

Anaduaka, U. S., \& Okafor, C. F. (2013). Poor performance of Nigerian students in mathematics in senior secondary certificate examination (SSCE): What is not working? Journal of Research in National Development, 11, 1-5.

Aquino, L. B. (2011). Study habits and attitudes of freshmen students: Implications for academic intervention programs. Journal of Language Teaching and Research, 2, 1116-1121. doi:10.4304/jltr.2.5.1116-1121

Ayodele, O. J. (2011). Gender difference and performance of secondary school students in mathematics. European Journal of Educational Studies, 3, 173-179.

Bakare, C. G. M. (1977). Study Habits Inventory (SHI). Ibadan, Nigeria: Education Research Production Psychology.

Crede, M., \& Kuncel, N. R. (2008). Study habits, skills, and attitudes: The third pillar supporting collegiate academic performance. Perspectives on Psychological Science, 3, 425-453.

De Paola, M., \& Scoppa, V. (2010). Frequency of examinations and student achievement in a randomized experiment. Rende, Italy: Dipartimento di Economia e Statistica, Università Della Calabria.

Deck, D. W. (2008). The effects of frequency of testing on college students in principles of marketing course (Doctoral dissertation). Virginia Polytechnic Institute and State University, Blacksburg, Virginia.

Devine, A., Fawcett, K., Szucs, D., \& Dowker, A. (2012). Gender differences in mathematics anxiety and the relation to mathematics performance while controlling for test anxiety. Behavioral and Brain Functions, 8, 2-9. doi:10.1186/1744-9081-8-33

Fakeye, D. O., \& Amao, T. A. (2013). Classroom participation and study habit as predictors of achievement in literature-in-English. Cross-Cultural Communication, 9, 18-25. doi:10.3968/j.ccc.1923670020130903.2741

Federal Ministry of Education, Science, and Technology. (1985). A handbook on continuous assessment. Ibadan, Nigeria: Heinemann Educational Books Limited.

Federal Republic of Nigeria. (2013). National policy on education. Lagos, Nigeria: NERDC Press.

Ganai, M. Y., \& Mirashraf, M. (2013). A comparative study of adjustment and academic achievement of college students. Journal of Educational Research and Essays, 1, 5-8.

Greaney, V. (2001). Using assessment to improve the quality of education. Paris, France: UNESCO International Institute for Education Planning.

Haigh, M. (2007). Sustaining learning through assessment: An evaluation of the value of weekly class quiz. Assessment \& Education in Higher Education, 32, 457-474. 
Ilogu, G. C. (2005). Educational research and evaluation. Lagos, Nigeria: Wealth Smith Books.

Jaiyeoba, A. O., \& Atanda, A. I. (2011). School quality factors and secondary school students' achievement in mathematics in south-western and north-central Nigeria. African Educational Research Network, 11, 91-100.

Joshi, G. (2000). Neuroticism, extraversion, and academic achievement as related to gender and culture. Indian Psychology Review, 54, 74-78.

Khurshid, F., Tanveer, A., \& Qasmi, A. N. (2012). Relationship between study habits and academic achievement among hostel living and day scholars' university students. British Journal of Humanities and Social Sciences, 3, 34-42.

Marcell, M. (2008). Effectiveness of regular online quizzing in increasing class participation and preparation. International Journal for the Scholarship of Teaching and Learning, 2, 7. doi: 10.20429/ijsotl.2008.020107

Mwebaza, M. (2010). Continuous assessment and students' performance in " $A$ " level secondary schools in Masaka district (Master's dissertation). Makerere University, Kampala, Uganda. Retrieved from http://mak.ac.ug/documents/Mafiles/theses/Mwebaza_Michael.pdf

Nuthanap, G. (2007). Gender analysis of academic achievement among high school students (Master's thesis). University of Agricultural Sciences, Karnataka State, India.

O'Kwu, E. I., \& Orum, C. C. (2012). Effect of continuous assessment scores on the final examination scores obtained by students at the junior secondary school (JSS) level in mathematics. Educational Research, 3, 706-709.

Parveen, A., Noor-Ul-Amin, S., \& Nazir, S. K. (2013). Comparative study of the academic achievement of 10th class boys and girls studying in different high schools of District, Pulwama. Journal of Education Research and Behavioral Sciences, 2, 20-27.

Sadia, B. (2005). A study of the factors affecting the performance of the students in government secondary schools for girls in Rawalpindi city (Master's dissertation). International Islamic University, Islamabad, Pakistan.

Shirvani, H. (2007). Effects of teacher communication on parents' attitudes and their children's behaviors at schools. Education, 128, 34-47.

Shirvani, H. (2009). Examining an assessment strategy on high school mathematics achievement: Daily quizzes vs. weekly tests. American Secondary Education, 38, 34-46.

Sud, A., \& Sujata, A. (2006). Academic performance in relation to self-handicapping, test anxiety and study habits of high school children. National Academy of Psychology, 51, 304309.

Tella, A. (2007). The impact of motivation on student's academic achievement and learning outcomes in mathematics among secondary school students in Nigeria. Eurasia Journal of Mathematics, Science \& Technology Education, 3, 149-156.

West African Examination Council. (2010-2014). Research division annual reports. Lagos, Nigeria: Author.

Zgraggen, F. D. (2009). The effect of frequent testing in the mathematics classroom (Masters dissertation). University of Wisconsin-Stout, Menomonie, Wisconsin.

Zhu, Z. (2007). Gender differences in mathematical problem solving patterns: A review of literature. International Education Journal, 8, 187-203. 


\section{Appendix}

\section{Study Habit Inventory: Section B}

Instruction: The following is a list of questions concerning students' habits and methods of study. Read and consider each statement and then indicate how it applies to you. Please answer all questions. After each statement, you will find columns 1, 2, 3, and 4. Place a check mark $(\sqrt{ })$ in the column that you feel best describes your study habits. Check it in accordance with the following key: 1 (almost never), 2 (less than half of the time), 3 (more than half of the time), and 4 (almost always).

\begin{tabular}{|c|c|c|c|c|c|}
\hline Item & Statement & 1 & 2 & 3 & 4 \\
\hline \multicolumn{6}{|c|}{ Homework and assignment } \\
\hline 1 & Do you complete your assignments on time? & & & & \\
\hline 2 & Do you begin your assignment as soon as the teacher gives them to you? & & & & \\
\hline 3 & Do you write down all assignments for each class in a special section of the notebook? & & & & \\
\hline 4 & $\begin{array}{l}\text { When you read and attempt to answer my homework, do you have in mind area where your } \\
\text { answer will be gotten from? }\end{array}$ & & & & \\
\hline 5 & Do you contact people to help you with your assignment? & & & & \\
\hline 6 & Do you take time to review your class notes before attempting the home work you were given? & & & & \\
\hline 7 & Do you review your assignment before writing test? & & & & \\
\hline 8 & Do you engage in group discussion when approaching your homework? & & & & \\
\hline 9 & Does homework given makes you read more facts about the topic taught by your teacher? & & & & \\
\hline \multicolumn{6}{|c|}{ Time allocation } \\
\hline 1 & Do you waste too much time listening to the radio for the good of your studies? & & & & \\
\hline 2 & Do you find that having many other things to do cause you to get behind in your school work? & & & & \\
\hline 3 & $\begin{array}{l}\text { Do problems outside of the classroom-with other students or at home-cause you to neglect } \\
\text { your school works? }\end{array}$ & & & & \\
\hline 4 & Do you study mathematics for at least 30 min each day after classes? & & & & \\
\hline 5 & Do you spend more time reading other subjects than mathematics? & & & & \\
\hline 6 & $\begin{array}{l}\text { Do you spend time involving in other activities that will improve your understanding of } \\
\text { mathematics? }\end{array}$ & & & & \\
\hline \multicolumn{6}{|c|}{ Reading and note taking } \\
\hline 1 & $\begin{array}{l}\text { After reading several pages of an assignment, do you find yourself unable to remember what you } \\
\text { have just read? }\end{array}$ & & & & \\
\hline 2 & Do you find it hard to pick out the important points of a mathematics assignment? & & & & \\
\hline 3 & $\begin{array}{l}\text { Do you have to re-read material several times because the solutions don't have much meaning the } \\
\text { first time you go over them? }\end{array}$ & & & & \\
\hline 4 & Do you have trouble picking out the important point in the mathematics exercises you solved? & & & & \\
\hline 5 & $\begin{array}{l}\text { Do you go back and check solution to exercises you have studied, rechecking any points you find } \\
\text { doubtful? }\end{array}$ & & & & \\
\hline 6 & $\begin{array}{l}\text { Do you miss important steps in mathematics class while copying down notes on something that } \\
\text { has gone before? }\end{array}$ & & & & \\
\hline 7 & $\begin{array}{l}\text { When you are having trouble with mathematics exercises, do you try talking it over with the } \\
\text { teacher? }\end{array}$ & & & & \\
\hline \multicolumn{6}{|c|}{ Study period procedures/test preparation } \\
\hline 1 & Do you need a long time to get warmed up when you want to start studying? & & & & \\
\hline 2 & Are you unable to study well because you get restless and unable to sit for long? & & & & \\
\hline 3 & When you sit down to study, do you find yourself too tired, bored, or sleepy to study well? & & & & \\
\hline 4 & Do you prefer to solve mathematics exercises alone rather than with others? & & & & \\
\hline 5 & $\begin{array}{l}\text { Do you seem to get very little done for the amount of time you spend solving mathematics } \\
\text { exercises? }\end{array}$ & & & & \\
\hline 6 & Do you find yourself beset by too many health problems to study efficiently? & & & & \\
\hline 7 & Do you find it hard to keep your mind on what you are studying for any length of time? & & & & \\
\hline 8 & Do outside interruptions disturb you while studying? & & & & \\
\hline \multicolumn{6}{|c|}{ Examinations/test taking } \\
\hline 1 & Do you do poorly on tests because of time? & & & & \\
\hline 2 & Do you get worried and confused when you did not do a test to your ability? & & & & \\
\hline 3 & When getting ready for a test, do you plan the way you will attempt your questions? & & & & \\
\hline 4 & Are you careless about steps and orderings when attempting mathematics exercises? & & & & \\
\hline 5 & Are you unable to finish test within the time allowed? & & & & \\
\hline 6 & Do you find out that you did not do well in test because of careless mistakes? & & & & \\
\hline 7 & Do you finish your mathematics examination/test before time? & & & & \\
\hline
\end{tabular}

Note. Adapted from the SHI by Bakare (1977). 
The Journal of Educational Research and Practice provides a forum for studies and dialogue that allows readers to better develop social change in the field of education and learning. Journal content may focus on educational issues of all ages and in all settings. It also presents peer-reviewed commentaries, book reviews, interviews of prominent individuals, and additional content. The objectives: We publish research and related content that examines current relevant educational issues and processes aimed at presenting readers with knowledge and showing how that knowledge can be used to impact social change in educational or learning environments. Additional content provides an opportunity for scholarly and professional dialogue regarding that content's usefulness in expanding the body of scholarly knowledge and increasing readers' effectiveness as educators. The journal also focuses on facilitating the activities of both researcher-practitioners and practitioner-researchers, providing optimal opportunities for interdisciplinary and collaborative thought through blogging and other communications.

Walden University Publishing: http://www.publishing.waldenu.edu 